\title{
The Accounting Provisions of the Foreign Corrupt Practices Act: An Alternative Perspective on SEC Intervention in Corporate Governance
}

The Foreign Corrupt Practices Act of 1977 (FCPA) ${ }^{1}$ was passed amidst public uproar over corporate bribes and illegal payments. ${ }^{2}$ In addition to prohibiting certain corporate payments, ${ }^{3}$ the FCPA added new accounting provisions ${ }^{4}$ to the Securities Exchange Act of 1934 (Exchange Act). ${ }^{5}$ New section $13(\mathrm{~b})(2)(\mathrm{A})$ (record-keeping amendment) of the Exchange Act requires corporations to keep accurate books and

1. Pub. L. No. 95-213, tit. I, 91 Stat. 1494 (1977) (codified at 15 U.S.C. $\S \S 78 m, 78 d d-1$, 78dd-2, 78ff (Supp. II 1978)).

2. See, e.g., Wall St. J., Apr. 14, 1975, at 1, col. 1 (United Brands payments to Honduran officials); Egan, Global Payoff Survey, Wash. Post, June 22, 1975, § F, at I, col. 1; Oversight on the Lockheed Loan Guarantee: Hearings Before the Senate Comm. on Banking, Housing and Urban Affairs, 94th Cong., 2d Sess. (1976) (testimony on Lockheed foreign payments).

3. The FCPA prohibits payments or offers of payments to foreign officials, candidates, or political parties to influence their official actions. 15 U.S.C. $\$ \S 78 \mathrm{dd}-1,78 \mathrm{dd}-2$, $78 \mathrm{ff}$ (Supp. II 1978). For a more detailed discussion of the foreign bribery provisions, see Atkeson, The Foreign Corrupt Practices Act of 1977: An International Application of SEC's Corporate Governance Reforms, 12 INT'L LAw. 703 (1978).

4. I5 U.S.C. $\$ 78 \mathrm{~m}(\mathrm{~b})(2)$ (Supp. II 1978). Congress incorporated the accounting standards into the FCPA in order to reinforce its criminalization of corporate foreign bribery. $S$. REP. No. 114, 95th Cong., Ist Sess. 7, reprinted in [1977] U.S. Code Cong. \& AD. News 4098, 4104-05 [hereinafter cited as SENATE Report with page citations to U.S. CodE Cong. \& AD. NEws]. Investigations into illegal domestic political contributions by the Office of the Watergate Special Prosecutor, subsequent investigations by the SEC into questionable domestic and foreign payments, and the SEC's program of voluntary disclosure of questionable payments, see Securities and EXchange Commission, RePort on Questionable AND Illegal Corporate Payments and Practices (Comm. Print May 12, 1976) (submitted to the Senate Comm. on Banking, Housing and Urban Affairs, 94th Cong., 2d Sess.) (summarizing corporate filings under program) [hereinafter cited as MAY 12 REPORT], revealed that such payments had been facilitated and concealed by falsifying records and maintaining off-the-books slush funds. Id. at 3. See Rankin, Accounting Ruses Used in Disguising Dubious Payments, N.Y. Times, Feb. 27, 1978, § D, at 1, col. 1. See generally Herlihy \& Levine, Corporate Crisis: The Overseas Payment Problem, 8 LAw \& PoL'y INT'L Bus. $547,547-68$ (1976) (describing incidence of foreign bribes and methods used to facilitate such payments).

5. 15 U.S.C. $\$ \S 78 \mathrm{a}-78 \mathrm{kk}$ (1976 \& Supp. II 1978) [hereinafter cited as Exchange Act]. 
records. ${ }^{6}$ New section $13(b)(2)(B)$ (internal controls amendment) requires issuers to maintain a system of internal accounting controls to provide reasonable assurances that transactions are executed in accordance with management authorization and are properly reflected on the corporation's books and records. ${ }^{7}$

These accounting provisions were codified as separate amendments to the Exchange Act and apply to issuers regardless of any involvement in foreign bribery or overseas operations. In addition, because the provisions contain no special sanction, they subject violating issuers to the existing sanctions of the Exchange Act, which include wide enforcement remedies $^{8}$ and criminal liability. ${ }^{9}$ The Securities and Exchange Commission has responded to this regulatory potential by interpreting the new accounting requirements to authorize more direct

6. (2) Every issuer which has a class of securities registered pursuant to section $78 l$ of this title and every issuer which is required to file reports pursuant to section 780 (d) of this title shall-

(A) make and keep books, records, and accounts, which, in reasonable detail, accurately and fairly reflect the transactions and dispositions of the assets of the issuer...

15 U.S.C. $\$ 78 \mathrm{~m}(\mathrm{~b})(2)$ (A) (Supp. II 1978).

7. (2) Every issuer which has a class of securities registered pursuant to section $78 l$ of this title and every issuer which is required to file reports pursuant to section $78 o$ (d) of this title shall ...

(B) devise and maintain a system of internal accounting controls sufficient to provide reasonable assurances that-

(i) transactions are executed in accordance with management's general or specific authorization;

(ii) transactions are recorded as necessary (I) to permit preparation of financial statements in conformity with generally accepted accounting principles or any other criteria applicable to such statements, and (II) to maintain accountability for assets;

(iii) access to assets is permitted only in accordance with management's general or specific authorization; and

(iv) the recorded accountability for assets is compared with the existing assets at reasonable intervals and appropriate action is taken with respect to any differences. I5 U.S.C. $\$ 78 \mathrm{~m}(\mathrm{~b})(2)(B)$ (Supp. II 1978).

8. See, e.g., Exchange Act $\$ 21(a)$, 15 U.S.C. $\$ 78 \mathrm{u}(\mathrm{a})$ (1976) (broad investigative authority for suspected violations); $\$ 21(b)$, 15 U.S.C. $\$ 78 u(b)$ (1976) (power to subpoena witnesses and require production of records); $\$ 21(d), 15$ U.S.C. $\$ 78 u(d)$ (1976) (power to seek civil injunction); Rule 2(e) of SEC Rules of Practice, 17 C.F.R. $\$ 201.2(e)$ (1979) (disciplinary administrative actions barring professionals from practicing before the SEC). In addition, because the accounting provisions amended section 13 of the Exchange Act, administrative proceedings under section 15(c)(4) of the Exchange Act, 15 U.S.C. $\$ 78 o(c)(4)$ (1976), might be available. Under this provision, if the SEC finds that any person has violated section 13, the Commission can publish its findings and issue an order requiring such person to comply with section 13 in the terms and conditions it specifies. See Block \& Barton, Administrative Proceedings to Enforce the Foreign Corrupt Practices Act, 7 SEc. REG. L.J. 40 (1979) (use of section $15(c)(4)$ proceedings to remedy FCPA violations would provide appropriate alternative to traditional injunctive actions).

9. See Exchange Act $\$ 32(a), 15$ U.S.C. $\$ 78 \mathrm{ff}(\mathrm{a})$ (1976) (willful violations of any provision of Act subject to penalties of up to $\$ 10,000$ fine or five years imprisonment, or both). 
agency involvement in the internal affairs of registered corporations. Such an interpretation could greatly increase public influence in corporate governance. ${ }^{10}$

This Note argues that those provisions were intended only to reinforce the existing disclosure framework of the Exchange Act, and that further SEC involvement in corporate affairs beyond this framework is an unauthorized and unwarranted exercise of agency discretion. The Note proposes a set of guidelines that would enable the SEC to protect investors under the disclosure mandate of the Exchange Act, as amended by the new accounting provisions, without intervening unduly in corporate governance.

\section{The SEC's Expansive Interpretation of the Accounting Provisions}

The accounting provisions of the FCPA were framed in ambiguous, far-ranging terms that could be interpreted as expanding the scrutiny of the Exchange Act to reach management decisionmaking. The SEC has adopted such an interpretation, assuming a more active supervisory role over the internal operations and structure of corporations.

\section{A. The Ambiguous Language of the Accounting Amendments}

The SEC, the chief enforcement agency under the Exchange Act, ${ }^{11}$ was the source of the FCPA accounting standards. ${ }^{12}$ Those standards, however, are described ambiguously in the statute, using such undefined terms as "accurately and fairly" and "reasonable assurances." 13

10. "Corporate governance" as used in this Note refers to the organizational structure and management hierarchy controlling the internal operations of the corporation. See The Role of the Shareholder in the Corporate World: Hearings before the Subcomm. on Citixens and Shareholders Rights and Remedies of the Senate Comm. on the Judiciary, 95th Cong., 1st Sess., Part 1, at 4, 8-9 (1977) (testimony of Philip Loomis, SEC Commissioner, discussing distinction between corporate governance and corporate accountability, and the SEC's role in each). But see AMerican Assembly, Running the American CoRporation vii (1978) (describing a broader, popular usage of corporate governance which encompasses the influences that determine what a corporation may or may not do).

11. The SEC has authority to sue issuers for civil violations of the Act under the FCPA provisions, 15 U.S.C. $\$ 78 \mathrm{ff}(\mathrm{c})$ (Supp. II 1978), and pre-existing section 21 of the Exchange Act, 15 U.S.C. $\$ 78 \mathrm{u}$ (1976). The Justice Department has authority to sue domestic concerns for civil violations of the FCPA, 15 U.S.C. $\S 78 \mathrm{dd}-2(c)$ (Supp. II 1978), and to prosecute both issuers and domestic concerns for criminal violations, 15 U.S.C. $\$ \S 78$ dd-1, 78dd-2 (Supp. II 1978). See Senate Report, supra note 4, at 4109-10.

12. The Senate version of the FCPA, S. 305, 95th Cong., Ist Sess. (1977), adopted the amendments to section 13(b)(2) of the Exchange Act that the SEC had suggested in its May 12 Report. The wording of the provisions eventually adopted by the conference committee was virtually identical to that earlier version. Compare MAY 12 REPORT, supra note 4, at 63-64 with H.R. REP. No. 831, 95th Cong., Ist Sess. 1 (1977).

13. 15 U.S.C. $\$ 78 \mathrm{~m}(\mathrm{~b})(2)(\mathrm{A})$-(B) (Supp. II 1978). 
This lack of specificity, combined with the amendments' applicability to all business activities of issuers registered under the Exchange Act, invites broad coverage. ${ }^{14}$ By relying upon the suggestions of the SEC, ${ }^{15}$ and by adopting such vague language, Congress made possible expansive SEG interpretation of the FCPA accounting standards.

Congress did qualify the accurate record-keeping requirement with the phrase "in reasonable detail"; ${ }^{16}$ it also recognized the need for cost-benefit considerations in the development by management of an internal control system. ${ }^{17}$ Congress failed, however, to incorporate a materiality standard ${ }^{18}$ into the accounting provisions. Because an accounting breach need not result in material reporting distortions in order to constitute a violation, the provisions have caused widespread confusion among managements and independent auditors concerning the adequacy of recording and internal control systems. ${ }^{19}$ Managers are forced to choose between the risk of violating the statute and the necessity of constructing elaborate and expensive control systems.

The imprecise limitation on the type of controls encompassed by the internal controls amendment also contributes to the confusion surrounding its interpretation. The amendment's definition of the objectives of the internal control system was derived ${ }^{20}$ from the description

14. Cf. Block \& Barton, supra note 8, at $52-53$ ("unrestrained use" of section $15(c)(4)$ in contested proceedings, coupled with far-reaching provisions of the FCPA "would make this enforcement tool a potent weapon in the hands of the Commission').

15. Congress engaged in relatively limited discussion of the accounting aspects of the bribery problem and instead relied on the assertions of the SEC. See SENATE REPORT, supra note 4 , at $4104-05$.

16. 15 U.S.C. $\$ 78 \mathrm{~m}(\mathrm{~b})(2)(\mathrm{A})$ (Supp. II 1978). The conference committee adopted the "in reasonable detail" qualification to the accurate and fair requirement "in light of the concern that such a standard, if unqualified, might connote a degree of exactitude and precision which is unrealistic." H.R. REP. No. 831, 95th Cong., lst Sess. 10, reprinted in [1977] U.S. Code Cong. \& AD. News 4121, 4122 [hereinafter cited as Conference Report with page citations to U.S. CoDE CONG. \& AD. NEws].

17. This consideration would permit managerial discretion in complying with the standard. See SENATE REPORT, supra note 4 , at 4106 .

18. Materiality is a basic feature of financial accounting: financial reporting is only concerned with information that is significant enough to affect evaluations or decisions. Accounting Principles Board Statement No. 4, Basic Concepts and Accounting Principles Underlying Financial Statements of Business Enterprises $\mathbb{f} 128$ (Oct. 1970), reprinted in Financial Accounting Standards Board, Financial Accounting Standards 437, 461 (1979). In considering whether misstatements are material, one factor to be considered is the dollar magnitude of the effects, as well as the pervasiveness of the misstatement in the financial statements taken as a whole. [1979-1] American Institute of Certified Public Accountants, Professional Standards AU $\$ 509.16$ [hereinafter cited to AU sections]. See notes 31 \& 52 infra (describing materiality standard in context of SEC's disclosure rules and Exchange Act).

19. See, e.g., Cook \& Kelley, Internal Accounting Control: A Matter of Law, J. AcCountancY, Jan. 1979, at 56, 60 (discussing confusion concerning extent of possible violations); Schiff \& Sorter, An Accountant Is Not a Chairman, N.Y. Times, Apr. 1, 1979, $\$ 3$, at 16, col. 3 (internal control section has created confusion by incorporating language originally designed for quite different purposes).

20. See SENATE REPORT, supra note 4 , at 4105 . 
in accounting literature of accounting controls, ${ }^{21}$ as distinguished from administrative controls. Accounting controls are concerned with the physical safeguarding of assets in processing transactions and with the reliable recording of such asset dispositions. ${ }^{22}$ Administrative controls, on the other hand, are concerned with the organizational structure and system of management authorization; they insure that decisions are reached in accordance with the corporation's overall objectives. ${ }^{23}$ The definitions are not mutually exclusive, and the line between them is difficult to draw. ${ }^{24}$ Both are facets of a company's general internal control system, and any accounting control system involves a corresponding set of administrative controls. ${ }^{25}$

Hence, if the distinction between administrative and accounting controls is not maintained, the statutory reach into corporate decisions is unlimited. A literal reading of the internal controls amendment's requirement that transactions be executed in accordance with management's general or specific authorization could extend Exchange Act coverage to a system of administrative controls. ${ }^{26}$ For example, a lower management decision to solicit sales in a territory that upper management has chosen not to serve could be viewed as unauthorized by upper management, or inconsistent with corporate objectives. Expenditures on research for a product already being manufactured, although properly recorded and intentional, could similarly be considered to violate the FCPA internal control requirement. ${ }^{27}$

21. The definition of the objectives of a system of accounting control contained in subparagraphs (i)-(iv) of section 13(b)(2)(B), see note 7 supra (quoting statutory language), was taken from AICPA auditing standards, Statement on Auditing Standards No. 1 (Nov. 1972). See AMerican Institute of Certified Public Accountants, supra note 18, $\$ 320.28$ (defining accounting control).

22. American Institute of Certified Public Accountants, supra note 18, $\$ 320.28$.

23. Id. $\$ 320.27$.

24. Id. \$ 320.29 .

25. Id. $\S 320.27$ (administrative controls are starting point for establishing accounting controls).

26. The authoritative auditing literature admits that the definition of accounting control could be interpreted broadly to mean that protection of existing assets and acquisition of additional assets is the primary function of management and that any procedures or records entering into management's decisionmaking processes are comprehended in that definition. Id. $\$ 320.14$. The AICPA standard rejected this broad definition and adopted a narrower definition. Id. $\S 320.19$. The courts could adopt this broader, literal definition of accounting control as used in section 13(b)(2)(B) (the internal controls amendment) on the ground that section $13(\mathrm{~b})(2)(B)$ is aimed at management, whereas the accounting literature is aimed at the auditor and the examination of the financial statements, and that the accounting literature therefore is not dispositive. See Schiff \& Sorter, supra note 19 (describing differing aims of the accounting literature and the FCPA).

27. Other examples of decisions that could be evidence of improper administrative controls, and of improper accounting controls under a broad definition, are a management decision to sell a product at a price that proves to be unprofitable, or a management decision to incur expenditures for equipment that proves to be inefficient, for materials that prove to be unsatisfactory in production, for merchandise that proves to be 


\section{B. The SEC's Actions Under Section 13(b)(2)}

Relying on these ambiguities, the SEC has acted to strengthen its role in corporate governance. In particular, the agency's interpretation of the FCPA accounting provisions has developed along lines independent both of foreign bribery and of financial materiality. The first court action brought by the SEC under the FCPA, SEC v. Aminex Resources Corp., ${ }^{28}$ contained no claims of foreign bribery or questionable payments, indicating the independent importance of the accounting amendments. ${ }^{29}$ In subsequent enforcement actions that did involve foreign payments, the Commission has questioned the proper functioning of internal administrative controls over corporate expenditures and has alleged defects in internal accounting controls from evidence of unrecorded transactions. ${ }^{30}$ The accounting violations in these enforcement proceedings have not always been material to resulting financial disclosures. ${ }^{31}$

unsaleable, or for research that proves to be unproductive. AMErican INSTTrute of CerTified Public Accountants, supra note $18, \S 320.14$. But see Cook \& Kelley, supra note 19 , at 60 (Congress did not intend recognition of such types of violations).

28. [1978 Transfer Binder] FED. SEC. L. REP. (CCH) \96,352 (D.D.C. Mar. 9, 1978).

29. The action charged the corporation, its president, vice-president, and various owned companies with violations of new section $13(\mathrm{~b})(2)$ and the antifraud and reporting provisions of the Exchange Act in connection with the misappropriation and diversion of at least $\$ 1.24$ million of corporate assets, which had been disguised by maintaining false entries on the corporate books and records. $I d$. A consent judgment was reached providing ancillary relief including the establishment of a proper system of accounting controls. See SEC v. Aminex Resources Corp., [1978 Transfer Binder] FED. SEC. L. REP. (CCH) I 96,458, at 93,657-58 (D.D.C. May 24, 1978).

In fact, only one of the six cases brought by the SEC under the FCPA has charged violations of the antibribery provisions, see SEC v. Katy Indus., Inc., 469 SEC. REG. \& $L$. REP. (BNA) A-1 (N.D. Ill. Aug. 30, 1978) (charging Katy Industries and two of its directors with making payments of $\$ 316,250$ to an Indonesian official and his associates to obtain $\$ 10$ million contract with country's state-owned oil and gas company), although the case against Aminex was the only one not involving foreign payments.

30. See, e.g., SEC v. Page Airways, Inc., [1978 Transfer Binder] FEd. SEc. L. REP. (CCH) 196,393 (D.D.C. Apr. 12, 1978) (alleging violations of sections 13(b)(2), 10(b), 13(a) and 14(a) of the Exchange Act). The complaint alleged that the corporation had made payments in excess of $\$ 2.5$ million to foreign officials in connection with over $\$ 60$ million of sales of goods and services by Page between 1971 and 1978. Id. at 93,391. The SEG alleged that the disbursements had been improperly and incompletely recorded as sales discounts and service payments and that Page's internal control system was not adequate to determine whether the "services provided" in connection with the falsely-labeled expenditures "were commensurate with the amounts paid." Id. at 93,392. Such analysis of the adequacy and need for services is an example of an administrative, not an accounting, function, which should not be encompassed under section $13(b)(2)(B)$ (the internal controls amendment), at least outside of the specific foreign bribery context.

31. See, e.g., SEC v. Page Airways, Inc., [1978 Transfer Binder] FED. SEC. L. ReP. (CCH) I 96,393, at 93,391 (D.D.C. Apr. 12, 1978) (payments of $\$ 2.5$ million in connection with $\$ 60$ million sales); SEC v. Katy Indus., Inc., 469 SEC. REG. \& L. REP. (BNA) A.I (N.D. Ill. Aug. 30, 1978) (payments of $\$ 316,250$ in connection with $\$ 10$ million contract). Although such amounts would not be financially material under the accounting definition of 
In addition, the public pronouncements and rulemaking proceedings of the SEC have emphasized the breadth and importance of the new accounting provisions. ${ }^{32}$ The first two rules promulgated under the amendments prohibit falsification of corporate books and records ${ }^{33}$ and prohibit making any false or misleading statements to accountants in connection with an audit. ${ }^{34}$ Adoption of these rules signified that the SEC believes that the accounting amendments give it authority to enact rules expressly governing the conduct of individuals within the corporation. In promulgating the rules, the SEC emphasized that the FCPA accounting provisions were not concerned exclusively with the preparation of financial statements ${ }^{35}$ and that these new requirements might provide an independent basis for enforcement actions, whether or not

materiality, see note 18 supra, disclosure of such immaterial foreign bribery might be permissible given Congress' intent to use section $13(\mathrm{~b})(2)$ to reinforce the criminalization of foreign bribery, see note 4 supra. The SEC has indicated, however, that no materiality standard would be applied to any section $13(\mathrm{~b})(2)$ violation, whether or not it involves foreign pasments. See Securities and Exchange Commission, 44th ANnual Report 21 (1978) (enforcement actions available under FCPA accounting requirements even if violations do not lead to dissemination of materially false information).

The SEC's disclosure rules and enforcement actions are generally limited to information that is material. See Herlihy \& Levine, supra note 4, at 570. The SEC departed from the cconomic materiality standard earlier in its enforcement actions for nondisclosure of questionable payments prior to the FCPA, alleging that foreign bribery was material in a nonquantitative sense. See id. at 573-77 (describing materiality of questionable payments per se). But see note 98 infra (criticizing SEC's per se rule of materiality).

32. See, e.g., Opening Statement of Harold Williams, SEC Chairman, at SEC's Consideration of Rulemaking Proposals Announced in Securities Exchange Act Release No. 13,185, at 1 (Jan. 31, 1979) (agency must be "responsible in giving substance to this broad new mandate").

33. Rule 13b2-1, 17 C.F.R. \$240.13b2-1 (1979).

34. Rule 13b2-2, 17 C.F.R. \$ 240.13b2-2 (1979).

These substantive prohibitions were included in the May 12 Report's suggested legislation, as proposed amended sections $13(\mathrm{~b})(3)$ and $13(\mathrm{~b})(4)$. MAX 12 REPORT, supra note 4 , at 64. When Congress adjourned without taking final action on the legislation, the Commission, on January 19, 1977, published proposed rules for public comment in language substantially identical to its four legislative proposals submitted to Congress, basing its authority to promulgate such rules on existing section 23(a) of the Exchange Act. Securities Exchange Act Release No. 13,185, 42 Fed. Reg. 4854 (1977). The Senate then adopted the four proposals in its version of the bill, but limited the prohibitions of proposed sections 13 (b)(3) and $13($ b)(4) to "knowingly" falsifying any book or record or "knowingly" making false or misleading statements to auditors, respectively, so that "inadvertent misstatements" or "minor discrepancies arising from an unwitting error in judgment" would not be actionable. SEN.tTe Report, supra note 4, at 4107 .

The conference committee later rejected these two sections and deleted them from the FCPA, because it did not want to turn the legislation into a discussion of the scienter requirement of Ernst \& Ernst v. Hochfelder, 425 U.S. 185 (1976). CoNFERENCE REPORT, supra note 16, at 4123. The SEC then withdrew the first two of its earlier rule proposals, which had been incorporated into the FCPA, and adopted the other two as Rules $13 \mathrm{~b} 2-\mathrm{I}$ and $13 \mathrm{~b} 2-2$, without any scienter requirement, basing its authority on sections 23(a) and 13(b)(2). Securities Exchange Act Release No. 15,570, 44 Fed. Reg. 10,964 (1979).

35. Securities Exchange Act Release No. 15,570, 44 Fed. Reg. 10,964, 10,966 (1979). 
their violation resulted in dissemination of materially false or misleading information. ${ }^{36}$

Two recent actions, justified under the authority of the amendments, further indicate the SEC's expansive use of its FCPA jurisdiction. In April 1979, the SEC proposed a rule ${ }^{37}$ that would have required management to include a statement of its internal accounting controls on Form $10-\mathrm{K}^{38}$ and in annual reports to security holders. ${ }^{39}$ Although an earlier private sector study had advocated voluntary reports of similar information, ${ }^{40}$ the SEC took the initiative to propose requiring the reports under the internal controls amendment to the Exchange Act. ${ }^{11}$ The Commission remarked that management's evaluation and related responsibility for internal controls might extend to "the overall control environment," involving consideration of "the organizational structure, including the role of the board of directors." 42

36. Id. at $10,966 \cdot 67$.

37. See Securities Exchange Act Release No. 15,772, 44 Fed. Reg. 26,702 (1979) [hereinafter cited as April 30 Release].

38. Id. Form 10-K is the SEC's filing form for annual reports required of issuers registered under the Exchange Act. See 17 C.F.R. $\$ 249.310$ (1979).

39. See 17 C.F.R. $\$ 240.14 a-3$ (1979) (requiring annual report be furnished to shareholders and specifying report's contents).

The proposed internal control report was to be implemented in two steps: from December 15,1979 to December 15, 1980, management was to give an opinion whether the internal control system provided reasonable assurance that the specified objectives of the FCPA requirements of section $13(\mathrm{~b})(2)(B)$ were being achieved, and to describe any material weaknesses in internal accounting control communicated by the independent accountants which had not been corrected. April 30 Release, supra note 37, 44 Fed. Reg. at 26.703-06; $c f$. note 95 infra (describing current investigation and report by independent accountants on internal control). During the second step, from December 15, 1980 on, an independent public accountant was to report whether management's opinion of the adequacy of its internal accounting controls was truthful and reasonable in light of the accountant's own evaluation. April 30 Release, supra note 37, 44 Fed. Reg. at 26,706-07.

40. See The Commission on Auditors' Responsibilities: Report, Conclusions and RecoMmendations 76-80 (1978) [hereinafter cited as Conen CoMmission RePORT].

41. April 30 Release, supra note 37, 44 Fed Reg. at 26,709.

The federal securities laws authorize the Commission to prescribe accounting practices to be applied in the preparation and presentation of financial statements included in filings with the Commission. The Commission, however, has historically looked to the standard-setting bodies designated by the accounting profession to provide leadership in establishing and improving accounting and auditing principles. Accounting Series Release No. 4, 11 Fed. Reg. 10,912 (1938); Accounting Series Release No. 150, 38 Fed. Reg. 1260 (1973). The SEG recognized the work of the Cohen Commission and the subsequent tentative AICPA recommendations, AMERICAN Institute of Certified Public Accountants, Tentative Conclusions and Recommendations of the Reports by Management Special Advisory Committee (Dec. 8, 1978), but felt such a management report on internal control should be required, not simply permitted, and should not be limited to errors or irregularities that could be material to the financial statements. April 30 Release, supra note 37, 44 Fed. Reg. at 26,702-03. The SEC also attempted to justify such disclosure under the pre-existing framework of the Exchange Act, believing that the information might be necessary to the interests of investors and other users of financial information to evaluate management's performance of its "stewardship responsibilities." Id.

42. April 30 Release, supra note 37, 44 Fed. Reg. at 26,705. On May 28, 1980, in the wake of substantial public opposition, the SEC withdrew its proposed rule. Securities Ex- 
Finally, the SEC has suggested that it could use the new accounting requirements to mandate independent audit committees for public companies. Shortly after the enactment of the FCPA, the SEC General Counsel responded to the Chairman's inquiry whether the Commission could require audit committees with an opinion that the most explicit authority for such a rule was the FCPA internal controls amendment. ${ }^{43}$ Although such a committee was not considered an element of internal control, it was to be deemed a "necessary means" of insuring that the internal control system was "operating in the manner intended." 44

\section{The Accounting Amendments Interpreted Within the Disclosure Framework of the Exchange Act}

The record-keeping and internal controls amendments added by the FCPA to the Exchange Act can be interpreted so as to have broad applicability independent of any involvement in foreign bribery. But expansive use of the new accounting provisions as statutory authority for direct intervention into corporate governance would distort the disclosure framework and purpose of the Exchange Act, to which the requirements were appended. The provisions should instead be interpreted as strengthening the reliability of the financial disclosure system. The adequacy of record-keeping and accounting control systems should be judged only by the accuracy of resulting financial statements.

\section{A. The Disclosure Framework of the Exchange Act}

To determine the extent of the SEC's authority under the accounting amendments, it is necessary to examine the statutory framework of the Exchange Act. The Act was designed to protect investors by providing them with an open market that would value securities at their fair price. The Act's primary means of achieving that market was by

change Act Release No. 16,877, 45 Fed. Reg. 40,134 (1980). The SEC intends, however, to monitor private-sector initiatives and solicit public comments until early 1982, when it will reconsider the question of mandatory management reports. Id.

43. Opinion of SEC General Counsel on the Commission's Authority to Require Public Companies to Establish Independent Audit Committees, [1978 Transfer Binder] FED. SEc. L. REP. (CCH) 981,535 , at 80,181 (Mar. 2, 1978). Alternative justifications for such a requirement under other sections were remarkably tenuous. See, e.g., id. at 80,180 (suggesting that SEC could require issuers to file periodic statements representing that auditors are engaged by independent audit committee, and that, because false or misleading statements are prohibited under the Exchange Act, this would have the effect of requiring issuers to establish independent audit committees).

44. Id. at 80,181 . The SEC is currently evaluating the existing prevalence of audit committees and plans to consider, on concluding its investigation, whether it should require the establishment of audit committees. See Securities and Exchange Commission Report to Congress on the Accounting Profession and the Commission's Oversight Role, [1979 Transfer Binder] FED. SEc. L. REP. (CCH) If 82,120, at 81,956 (June 28, 1979). 
disclosure of information materially important to investors, ${ }^{45}$ a system intended to enable investors to make informed investment decisions ${ }^{46}$ and shareholders to exercise their suffrage rights. ${ }^{47}$ Disclosure was also intended to prevent securities manipulation and to protect investors from fraud. ${ }^{48}$

Congress adopted disclosure as a regulatory method because of its desire to minimize governmental intervention in corporate affairs..$^{40}$ The Exchange Act intended disclosure to reveal only those activities prohibited by independent law or clearly material to investor interests. ${ }^{50}$ The courts, and even the SEC, have recognized that, given Congress' adoption of the disclosure mechanism, substantive regulation of business is beyond the SEC's statutory discretion. ${ }^{51}$ The ma-

45. Congress rejected direct regulation of corporate organization by the federal government and instead adopted a limited approach designed to enhance securities distribution and trading processes. See H.R. REP. No. 1383, 73d Cong., 2d Sess. 2 (1934) [hereinafter cited as H.R. REP. No. 1383]; Sommer, The Impact of the SEC on Corporate Governance, LAw \&: Contemp. Prob., Summer 1977, at 115, 118.

46. H.R. REP. No. 1383 , supra note 45 , at 11 .

47. Id. at 13-14.

48. Such activities depend on nondisclosure for their effect. L. Brandeis, Other PeoPLE'S MONEY AND How THE Bankers Use It 92-104 (1914); Anderson, The Disclosure Process in Federal Securities Regulation: A Brief Review, 25 Hastings L.J. 311, 329-31 (1974); Sommer, supra note 45, at 119 .

49. H.R. REP. No. 1383, supra note 45, at 3; S. REP. No. 792, 73d Cong, 2d Sess. 10 (1934) (Senate version contained subsection 13(d) which provided that nothing in act should be construed to authorize Commission to interfere with management of affairs of an issuer); see Frankfurter, The Federal Securities Act: $I I, 8$ ForTuNE 53, 55 (Aug. 1933) (until less drastic remedies fail, federal government should not embark on federal incorporation or exercise direct control over investments); Anderson, supra note 48, at 319-20; Sommer, supra note 45 , at 118 .

50. See notes 31 \& 48 supra.

51. See SEC v. American Realty Trust, 429 F. Supp. 1148, 1178 (E.D. Va. 1977) (SEC and courts are bound to respect limits inherent in statutory scheme aimed at ensuring disclosure in securities sales and not substantive regulation of business itself); Securities Act Release No. 5627, 40 Fed. Reg. 51,656, 51,660 (1975) (environmental disclosure; Commission may not require disclosure solely in order to affect directly corporate conduct); cf. Advisory Commttee on Corporate Disclosure, 95th Cong., 1st Sess., Report to the Securities and Exchange Commission D-8, 318-19 (Comm. Print 1977) (suggesting Commission adopt statement of objectives recognizing that it should not adopt disclosure requirements that have as their principal objective the regulation of corporate conduct). But cf. Preliminary Response of the Commission to the Recommendations of the Advisory Commiltee on Corporate Disclosure, Securities Act Release No. 5906, [1978 Transfer Binder] FED. SEc. L. REP. (CCH) I 81,505, at 80,048 (Feb. 15, 1978) (rejecting Advisory Committee's suggestion, because Congress was aware that decisions on required disclosure frequently affect conduct).

Several commentators have suggested active use of the disclosure mechanism to coerce and restructure corporate conduct, see, e.g., Sonde \& Pitt, Utilizing the Federal Securities Laws to "Clear the Air! Clean the Sky! Wash the Wind!", 16 How. L.J. 831 (1971) (suggesting disclosure of activities in area of environmental protection as additional weapon in federal arsenal directed at environmental problems); Weiss \& Schwartz, Using Disclosure to Activate the Board of Directors, LAw \& ConTEMP. Prob., Summer 1977, at 63 (advocating use of disclosure to strengthen board of directors), while at the same time they admit the 
teriality standard ${ }^{52}$ defines the limit of that discretion, preventing undue interference in internal corporate affairs.

The use of the Exchange Act's disclosure mechanism to intrude into the corporate structure, therefore, is devoid of statutory authority. Furthermore, the limited legislative history of the amendments ${ }^{53}$ indicates no contrary intention. Apart from their role in the criminalization of foreign bribery, the accounting standards were installed in order to strengthen the honesty of the record-keeping process, thus reinforcing the existing system of corporate disclosure and enhancing public confidence in the securities markets. ${ }^{54}$ Congress demonstrated no intent to alter the basic non-interventionist tenor of the Exchange Act in areas other than foreign payments.

\section{B. Section 13(b)(2) as Reinforcing Financial Disclosure Accuracy}

The accounting provisions should be interpreted in the context of the Exchange Act and thus should be enforced with the aim of providing material information to investors. Because a corporation's accounting system is designed to provide financial information, materiality in such a context refers to the relative size of any distortions in reported amounts. ${ }^{55}$ A corporation's books and records, regulated under the record-keeping amendment, should be sufficient to generate reliable financial statements containing no material omissions or misstatements.

SEC's lack of authority independently and substantively to regulate the conduct to be disclosed, Sonde \& Pitt, supra, at 849; Weiss \& Schwartz, supra, at 77 n.65, 84 n.93. But see, e.g., Knauss, A Reappraisal of the Role of Disclosure, 62 MicH. L. REv. 607, 647-48 (1964) (unanswered question whether securities laws can be used to force additional corporate disclosures that may be in public interest but cannot be justified as necessary for investor protection). Indeed, the SEC was criticized prior to the enactment of the FCPA for its attempt to prohibit corporate bribery by requiring disclosure of foreign payments, because it had no authority to forbid such payments. See Freeman, The Legality of the SEC's Management Fraud Program, 31 Bus. LAw, 1095 (1976); Note, Disclosure of Payments to Foreign Government Officials Under the Securities Acts, 89 HARv. L. Rev. 1848 (1976). Officers of the SEC attempted to justify such foreign bribery disclosures as being material to the investing public, see Doherty, The SEC'S Management Fraud Program, 31 Bus. LAw. 1279, 1280 (1976); note 31 supra, but admitted that they felt such foreign payments should be prohibited, see Sommer, The Disclosure of Management Fraud, 31 Bus. LAw. 1283, 1292-93 (1976). See note 98 infra (discussing such materiality reasoning).

52. See note 18 supra. Courts have developed the materiality standard for determining when omitted or misstated securities disclosures are actionable: the information is material if a reasonable investor would consider it important in deciding whether to invest, or, in proxy cases, if a reasonable shareholder would consider it important in deciding how to vote. See TSC Indus. v. Northway, Inc., 426 U.S. 438, 449 (1976); Affiliated Ute Citizens v. United States, 406 U.S. 128, 153-54 (1972); Mills v. Electric Auto-Lite Co., 396 U.S. 375, 384 (1970).

53. See note 15 supra.

54. Senate Report, supra note 4, at 4105; see Conference Report, supra note 16, at 4122 .

55. See note 18 supra. 
Materially inaccurate financial statements would indicate that the company's books are not adequate and would violate that section.

Similarly, a corporation's system of internal accounting controls is designed to safeguard the assets of the company and insure that transactions are properly recorded, permitting the preparation of reliable financial statements. ${ }^{56}$ The system should be deemed sufficient for financial disclosure purposes if it makes possible the generation of financial statements presenting the financial condition of the corporation without material omissions or distortions. Minor breaches in internal accounting controls that allow only non-material asset losses or that do not prevent proper accountability for material amounts should not be actionable. The SEC should only remedy internal accounting control defects under the internal controls amendment when they affect the integrity of the reporting process. Administrative controls over the decisionmaking process are not proper subjects for enforcement under the new provisions, because such controls are not concerned with the reliability of the investor-informing process.

The SEC has claimed that disclosure of internal control weaknesses and off-the-books recording, independent of any financial statement effects, is material to investors in the broad sense of assisting them in evaluating management integrity. ${ }^{57}$ Most studies on disclosures of improper activity during the SEC voluntary program, however, indicate that such disclosures have at most a minor effect on investor evaluation. ${ }^{58}$ The materiality of disclosing such weaknesses is thus highly

56. American Institute of Certified Public Accountants, supra note $18, \$ \S 320.19$, 320.28 .

57. April 30 Release, supra note 37, 44 Fed. Reg. at 26,702-03.

58. In a study of the transactions volume and stock price changes of securities of seventy-four firms that disclosed foreign payments from April 1975 through May 1976, Paul A. Griffin found that (l) the transactions volume for firms during the weeks surrounding disclosure was generally greater than the volume for similar non-disclosing firms, and firms that disclosed significant dollar payments experienced a higher transactions volume than those that did not; (2) the variability of residual price changes was greater for disclosing firms in the week following announcement, and firms disclosing significant dollar transactions were more affected than those whose payments were small or immaterial; and (3) the firms disclosing sensitive foreign payments experienced a small, temporary decline in the value of their common shares, but within two to three weeks the security price reverted back to normal levels. See Griffin, Sensitive Foreign Payment Disclosures: The Securities Market Impact, reprinted in ADVISORY CoMmitTeE ON CoRPORATE Disclosure, supra note 51, at 694-743. Griffin concluded that agents seem to respond differentially to the amount of the payments, and that the degree of concern by those in government did not appear commensurate with the small temporary impact of the disclosure on the value of the corporation. Id. at 730-34. Another, seemingly inconclusive, study of a sampling of eight companies disclosing foreign payments between March 25 and April 1, 1976, found that the declines in securities prices immediately following announcement were subsequently largely compensated for. Note, supra note 51, at 1855 n.45. Even a former SEC Commissioner has admitted that the "impact of these disclosures upon the behavior of corporate America would appear to exceed by far the impact on investors." Sommer, supra note 45 , at 135 . 
doubtful. Furthermore, this wider standard of materiality, based on notions of general investor relevancy, would make it difficult to establish any limits on disclosure requirements. ${ }^{59}$

The SEC itself earlier endorsed a strict materiality standard regarding non-financial disclosures. In response to a petition to adopt comprehensive disclosures regarding environmental and fair employment practices, ${ }^{60}$ the SEC adopted rules requiring disclosure only of material financial effects of compliance with environmental laws. ${ }^{61}$ After judicial instruction to consider the "ethical investor" interest in such information, ${ }^{62}$ the SEC refused to broaden the disclosure requirements, claiming that its authority was limited to disclosure of economically significant information in a narrow sense. ${ }^{63}$

This position is consistent with the original framework of the Exchange Act, unlike the more recent use of disclosure under the FCPA amendments to regulate corporate affairs on the basis of general investor relevancy. ${ }^{64} \mathrm{~A}$ proper materiality qualification for the new ac-

59. Many sorts of disclosures concerning corporate officers-including political affiliations, investment holdings, charitable contributions, employment practices, environmentalprotection efforts-could be required under such a broad standard, because these data also arguably reflect management integrity. See Friedman \& Leonard, Integrity and Management Disclosures: The Disclosure of Matters Bearing on Competence and Integrity, 7 INST. SEC. REG. 1, 14 (1976). Thus the general-investor-relevancy standard is unacceptably broad. By tying investor relevancy regarding books and records and internal controls to a financial-statement-materiality standard, relevancy can be determined on a consistent, quantifiable, and acceptably limited basis.

60. See Natural Resources Defense Council v. SEC, 389 F. Supp. 689, 693-95 (D.D.C. 1974).

61. Securities Act Release No. 5386, 38 Fed. Reg. 12,100 (1973) (codified at 17 C.F.R. $\$ \S 239.11,239.22,239.26,249.210,249.308,249.310$ (1979)).

62. Natural Resources Defense Council v. SEC, 389 F. Supp. 689, 700 (D.D.C. 1974). The court noted that ethical investors might believe that awareness of and sensitivity to environmental problems was the mark of intelligent management. It thus could not say that such information was not material within the meaning of the securities laws. Id.

63. Securities Act Release No. 5627, 40 Fed. Reg. 51,656 (1975); Securities Act Release No. 5704, 41 Fed. Reg. 21,632 (1976) (adopting limited disclosures regarding capital expenditures for environmental compliance purposes while rejecting broader proposals). The SEC felt the disclosed information should only be appropriate for the protection of investors or the furtherance of fair and informed securities markets. Securities Act Release No. 5627, 40 Fed. Reg. 51,656, 51,660 (1975). It believed that equal opportunity information could not be distinguished from over 100 other matters of social concern suggested as topics for disclosure, including biographical information regarding directors, interlocking directorates, control within a corporation, the role of the board of directors, and political contributions. $I d$. at $51,666 \&$ n.72. An appellate court finally sustained this exercise of discretion after deciding its review of the substantive rationality of the SEC's decision had to be narrow in scope. Natural Resources Defense Council v. SEC, [1979 Transfer Binder] Fed. Sec. L. ReP. (CCH) 996,832 (D.C. Cir. Apr. 20, 1979). The court noted that the Commission concluded that ethical investors were typically uninterested in the comprehensive disclosures suggested, and held that the SEC was, for this reason among others, justified in its action. Id. at 95,354.

64. The SEC has also recently used disclosure to regulate corporate affairs under other provisions. See Accounting Series Release No. 165, 40 Fed. Reg. 1010 (1975) (proxy disclosure concerning audit committee); Securities Exchange Act Release No. 15,384, 43 Fed. 
counting provisions would provide an interpretation of the FCPA accounting amendments in harmony with the Exchange Act disclosure mechanism.

\section{Guidelines for Narrative Disclosures Under the Amended Exchange Act}

The interpretive inconsistencies arising from an expansive use of the accounting provisions of the FCPA suggest the need for developing explicit guidelines for SEC narrative disclosure ${ }^{65}$ requirements. Such guidelines should be based on investment analysis principles. This would allow the SEC to achieve the goals of investor and suffrage protection under the Exchange Act without intervening in internal corporate affairs.

\section{A. A Framework for Disclosure}

Narrative disclosures may be analyzed according to the results they achieve; those results can be classified in terms of group pressure, enforcement, and informative effects. ${ }^{66}$ Only the enforcement and informative effects justify disclosures under the Exchange Act.

\section{Group Pressure Effect}

Disclosure can alter conduct by invoking group pressure against the discloser. ${ }^{67}$ The efficacy of disclosure for group pressure depends on the number and nature of the recipients, the degree to which they feel their vital interests are affected, and the range of alternative protective means available to them. ${ }^{68}$

Reg. 58,522 (1978) (disclosure concerning corporate boards of directors); MAY 12 REPORT, supra note 4, at 6-13 (describing voluntary disclosure program for questionable payments to avoid SEC enforcement action). The SEC justified these disclosure requirements in general terms of relevance to evaluating managerial integrity. See Accounting Series Release No. 165, 40 Fed. Reg. 1010, 1012 (1975); Securities Exchange Act Release No. 15,384, 43 Fed. Reg. 58,522, 58,523 (1978); MAY 12 REPoRr, supra note 4, at 19-20. Disclosure of such foreign bribery, management committees, and internal controls would seem to be indistinguishable from some of the 100 suggested disclosure items rejected by the SEC in 1976, see note 63 supra, as being irrelevant to investors and shareholders.

65. "Narrative disclosure" as used in this section refers to disclosure of non-financial information; that is, qualitative data not incorporated into the financial statements.

66. See Note, Disclosure as a Legislative Device, 76 HARv. L. REv. 1273, 1273-76 (1963).

67. Id. at 1274. This "group pressure" effect is to be distinguished from the "informative" effect of disclosure, under which the recipient may be able, by acting on his evaluation of the disclosed information, to protect his personal interests without having to alter the future conduct of the disclosers. Id. at 1274-75.

68. See id. at 1282 . 
The lack of enthusiasm with which shareholders ${ }^{60}$ exercise their limited control ${ }^{70}$ over corporate management has led many commentators to doubt the desirability of increasing their supervisory power over management decisionmaking. ${ }^{71}$ For most shareholders, disinvesting is a more cost-effective response to unsatisfactory management conduct than voting to alter such conduct. ${ }^{72}$ Disinvestment may itself have an effect analogous to group pressure, in that it could alter management conduct indirectly by lowering stock prices; ${ }^{73}$ for this to occur, however, the revealed conduct must be serious enough to provoke extensive disinvestment. For these reasons, disclosure used for its group pressure effect is a less effective deterrent to undesirable management conduct than is direct legislation. ${ }^{74}$

69. SEG-mandated disclosure under the Exchange Act is designed to benefit shareholders. See p. 1582 supra.

70. Shareholders generally can only approve or reject proposed candidates for the board, charter amendments, and major corporate transformations. See, e.g., Brudney \& Chirelstein, Fair Shares in Corporate Mergers and Takeovers, 88 HARv. L. Rev. 297, 299300 (1974) (describing ineffectiveness of shareholder voting in approving mergers); Manning, Book Review, 67 Yale L.J. 1477 (1958) (reviewing J. Livingston, The American STOCKHOLDER (1958) and describing shareholder impotency).

71. See, e.g., Eisenberg, The Legal Roles of Shareholders and Management in Modern Corporate Decisionmaking, 57 CaLIF. L. Rev. 1, 180 (1969) (questions of public policy do not lend themselves to solution through reorganization of corporate decisionmaking mechanism); Jones, The Relations between the Board of Directors and Operating Management, in AMERICAN Assembly, supra note 10, at 96, 102 (shareholders interested in financial results, not participation in corporate affairs); Manning, The Shareholder's Appraisal Remedy: An Essay for Frank Coker, 72 YALE L.J. 223, 261 (1962) (modern shareholder is investor, not owner or manager).

72. Members of an organization can respond to its deterioration by two mechanisms: "exit," the separation of the member from the organization, for example, by security disinvestment, and "voice," the expression of dissatisfaction directly to management, for example, by shareholder voting. Both mechanisms can alert management and induce the firm's recovery. A. Hirschman, Exir, Voice, and Loyalty 4, 15-16 (1970). The role of voice will generally decrease as the opportunities for exit increase. $I d$. at 34 . When both are available, the readiness to resort to voice over exit will depend on the substitutability of other organizations, and the extent to which the member can alter conduct. Id. at 36.41. Because disinvesting in publicly held corporations through the stock market is easy, close security substitutes are available, and altering corporate conduct is costly, informed shareholders will react to management deterioration through exit, rather than voice. $I d$. at 46 .

73. Cf. Manne, Cash Tender Offers for Shares $-A$ Reply to Chairman Cohen, 1967 DukE L.J. 231, 236-37 (describing pressure on management to keep share prices up). If management cannot respond to such pressure, lowered stock prices might induce a takeover that would replace existing management. $I d$. at 238-41.

74. See Breyer, Analyzing Regulatory Failure: Mismatches, Less Restrictive Alternatives, and Reform, 92 HaRv. L. Rev. 549, 579-80 (1979) (comparing disclosure regulation with standards governing primary conduct). Although disclosure is less restrictive, it is only effective when the public can understand the information and choose on the basis of it. Id. at 580. Because shareholders will not act on disclosed information by either disinvesting or voting unless they are very interested in its content, corporate disclosure will not be effective in regulating many areas of corporate affairs. 


\section{Enforcement Effect}

Disclosure operates as an enforcement mechanism when it permits investigation into, or forces exposure of, violations of substantive regulations. ${ }^{75}$ Disclosure requirements are particularly effective in securities regulation when they substitute private enforcement for agency regulation of illegal conduct. ${ }^{76}$

In order for the SEC to require public narrative corporate disclosures as an enforcement tool, however, the underlying conduct must violate existing statutory or common law norms, such as insider trading or fraud, and there must be a pre-existing private right of action to remedy the violation. ${ }^{77}$ Disclosure should not be used to override legislative determinations and create unintended private remedies. ${ }^{78}$ Moreover, in order to justify the added cost of required disclosure, the SEG should show that enforcement would be more difficult without it. ${ }^{79}$ Disclosure as an enforcement device, therefore, is justifiable in only a limited context.

\section{Informative Effect}

Disclosure is useful as an informative device when it enables the recipient to protect his own interests without altering the discloser's conduct. The Exchange Act was designed to provide information useful to shareholders in two situations: the investment decision and the shareholder voting decision. A criterion drawing on the courts' materiality

\section{See Note, supra note 66 , at $1273-74$.}

76. Section 16 of the Exchange Act, 15 U.S.C. $\$ 78 \mathrm{p}$ (1976), provides an excellent example of the use of narrative disclosure for its enforcement effect. See Note, supra note 66 , at 1280-82. Section 16(a) requires insiders to disclose their security holdings and transactions, and thus enables private shareholders to sanction unwanted insider activity under section 16(b), without requiring agency involvement. See id.

77. If the recipient of the information has no right to prevent any underlying prohibition, public disclosure serves no protective enforcement role.

78. See Ernst \& Ernst v. Hochfelder, 425 U.S. 185, 213-14 (1976) (rulemaking power granted to administrative agency is not power to make law, but to adopt regulations to carry into effect will of legislature).

79. The SEC has traditionally weighed the benefit of specific required disclosures against the cost of that disclosure. See MAY 12 REFORT, supra note 4, at 21. Such costbenefit analysis is consistent with recent executive and legislative actions minimizing the costs of compliance with agency regulations. See Exec. Order No. 12,044, 3 C.F.R. 152 (1979) (requiring executive agencies to consider cost-effectiveness of regulations and to file economic impact statement for agency proposals). Although, as an independent regulatory agency, the SEC is not bound by the Executive Order, supra, it has been asked to comply voluntarily with the Order's procedures. See 43 Fed. Reg. 12,665, 12,670 (1978). See also S. 262, 96th Cong., 1st Sess., 125 Cong. Rec. S861 (daily ed. Jan. 31, 1979); S. 755, 96th Cong., Ist Sess., 125 Conc. Rec. S3338 (daily ed. Mar. 26, 1979) (proposals to require all federal agencies to estimate and publish projected costs, benefits, and other impacts of major regulations before adoption). 
standard should be applied in determining the propriety of narrative disclosure for its informative effect. To serve its protective role, the information disclosed must be considered significant in the investment or voting decision.

Investment analysis principles ${ }^{80}$ can be used to determine materiality to the investment decision. An investor seeks to minimize risk while maximizing return..$^{81}$ For disclosures to be material to the investment decision, then, they must affect an investor's evaluation of these factors, which are directly reflected in the security's market price. ${ }^{82}$ In proposing narrative disclosure under this view of materiality, the SEC must correlate stock price responsiveness to the disclosure, thereby demonstrating that cash-flow, timing, or risk predictions are affected by the disclosure. Such responsiveness could be shown by studies of market reactions to similar disclosures in previous cases. ${ }^{83}$

Similar reasoning suggests that proxy disclosure, designed for its informative effect on the voting decision, be directly related to matters within the scope of shareholder voting power. ${ }^{84}$ The SEC should demonstrate that public disclosure is important to a particular decision and require such disclosure in the related proxy materials. The SEC will have no empirical guides to determine voting importance but could justify the disclosure by the size of the shareholder constituency interested in the type of uniform disclosure required. Disclosures appealing to more minor constituencies should be left to individual shareholder initiative under the existing shareholder proposal provisions of the proxy rules. ${ }^{85}$

80. See V. Brudney \& M. Chirelstein, Corporate Finance 1143-70 (2d ed. 1979); J. Lorie \& M. Hamilton, The Stock Market: Theories and Evidence 70-167 (1973). Investors are concerned with two aspects of a security: its risk and its return. V. BrudNeY \& M. Chirelstein, supra, at 1144; see B. Malkiel, A Random Walk Down Wall Street 74-81 (1975). Return is based on the future cash-generating ability of the corporation and the timing of such cash flows. Kripke, A Search for a Meaningful Securities Disclosure Policy, 31 Bus. LAw. 293, 301-04 (1975).

81. See W. Sharpe, Portfolio Theory and Capital Markets 26-30 (1970).

82. Cf. Note, Utilization of Investment Analysis Principles in the Development of Disclosure Policy Under the Federal Securities Laws, 25 U.C.L.A. L. REv. 292 (1977) (discussing consistency between judicial standards of materiality and financial theories regarding kinds of information material to investment process).

83. See, e.g., note 58 supra (discussing studies of effects of foreign bribery disclosure).

84. Cf. Mills v. Electric Auto-Lite Co., 396 U.S. 375, 384 (1970) (correction of trivial or unrelated proxy defect will not serve any protective purpose).

85. See Rule 14a-8, 17 C.F.R. $\$ 240.14 a-8$ (1979) (requiring management to include shareholder proposal and statement with proxy if shareholder notifies management of his intention to present a proposal at forthcoming shareholders meeting). Such shareholder proposal provisions can be used to bring socially responsible matters or topics of particular interest to the attention of management. See R. NADER, M. Green \& J. Seligman, Taming the Giant Corporation $80-83$ (1976) (Campaign GM); Schwattz, The Public-In- 


\section{B. Disclosure Guidelines Applied to Section 13(b)(2)}

The activities of the SEC in implementing the accounting provisions of the FCPA can be evaluated according to these guidelines. Under such an analysis, the SEC should refrain from using the accounting amendments as a group pressure device to affect corporate conduct or structure. Substantive regulations over the internal conduct of corporate officers, such as the adopted rules on record falsification and misleading statements to auditors, ${ }^{86}$ are inappropriate uses of the accounting amendments. ${ }^{87}$ Regulations that alter the corporate structure, such as the possible requirement of audit committees, ${ }^{88}$ are similarly unwarranted because they attempt to achieve an interventionist, group pressure effect. ${ }^{89}$

Disclosure also cannot be used for its enforcement effect because the accounting amendments do not grant any private right of action to shareholders. Although the legislative history of the FCPA indicates that some private right of action was intended for competitors suffering injury from foreign bribery, ${ }^{90}$ it does not refer to such a right under the

terest Proxy Contest: Reflections on Campaign GM, 69 Mich. L. Rev. 419 (1971). The most publicized instance, Campaign GM, attracted only $0.2 \%$ shareholder support, $R$. Nader, M. Green \& J. Seligman, supra, at 81 , and indicates the lack of sufficient shareholder interest to require disclosure in areas of public concern such as environmental protection and employment discrimination.

86. See p. 1579 supra.

87. Even if the rules were qualified so that only officer violations leading to material distortions in the financial statements were actionable, the rules would duplicate existing prohibitions and be unnecessary. Under section 10(b) of the Exchange Act, 15 U.S.C. $\$ 78 \mathrm{j}(\mathrm{b})(1976)$, and Rule $10 \mathrm{~b}-5$, 17 C.F.R. $\$ 240.10 \mathrm{~b}-5$ (1979), a private party can bring an action against officers for making untrue statements of, or omitting to state, material facts that are necessary to make those statements not misleading. See Ernst \& Ernst v. Hochfelder, 425 U.S. 185, 196 (1976); Blue Chip Stamps v. Manor Drug Stores, 421 U.S. 723, 730 (1975).

88. See p. 1581 supra.

89. A regulation requiring audit committees would also be undesirable for practical reasons because it would generate unrealizable expectations about the ability of such committees to remedy "all the inadequacies of the present system of corporate governance." See Greene \& Falk, The Audit Committee-A Measured Contribution to Corporate Governance: A Realistic Appraisal of its Objectives and Functions, 34 Bus. LAw. 1229, 1233-34 (1979); Jones, The Relations between the Board of Directors and Operating Management, in American Assembly, supra note 10, at 96, 97-98 (audit committee can deal with financial irregularities but is not a superboard dealing with social impact of corporate activities or with ethical requirements in non-financial areas).

90. The House report indicated that a private right of action was to be implied for foreign bribery violations under the House version of the bill. H.R. REP. No. 640, 95th Cong., Ist Sess. 10 (1977). The Senate and conference committee reports contained no mention of private rights of action. See SENATE REPORT, supra note 4; CONFERENCE REPORT, supra note 16. Based on this and other evidence, the SEC's Office of the General Counsel submitted its opinion that a private right of action should be implied for foreign bribery under the FCPA. Opinion of Office of the General Counsel on the Existence of a Privale Right of Action Under the Foreign Corrupt Practices Act of 1977, [1978 Transfer Binder] 
accounting provisions, ${ }^{91}$ and the courts are unlikely to infer one. ${ }^{92}$ Requiring management reports on internal controls in order to encourage private enforcement of disclosed defects is thus not warranted.

The accounting provisions of the FCPA can be used to reinforce directly the informative effect on investors of financial disclosures required under the Exchange Act. If a corporation's record-keeping and internal control systems are not adequate to prevent the formulation of materially misleading financial statements, then the FCPA accounting amendments give the SEC the authority to investigate and remedy the underlying financial-statement-generation process, authority that it previously lacked..$^{93}$ The SEC will be able to achieve more complete preventive relief against future misleading disclosures by seeking to establish adequate bookkeeping and internal control systems through enforcement actions. ${ }^{94}$

In requiring narrative public disclosures under the accounting amendments for their informative effect, especially outside the foreign

FED. SEC. L. REP. (CCH) \ 81,701 (May 16, 1978) [hereinafter cited as General Counsel Opinion]. See Siegel, The Implication Doctrine and the Foreign Corrupt Practices Act, 79 Col.um. L. REv. 1085, 1104-16 (1979) (private cause of action for injunctive relief, but not damages, should be implied for competitors under anti-bribery sections to provide preventive enforcement).

91. The House version of the bill, H.R. 3815, 95th Cong., Ist Sess., 123 Cong. Rec. H1313 (daily ed. Feb. 22, 1977), contained no accounting provisions, and the SEC opinion, General Counsel Opinion, supra note 90, did not consider the accounting provisions.

92. See Siegel, supra note 90, at 1104-12.

93. Although the SEC has had authority under the securities laws to prescribe principles to be used in the presentation of financial statements, see note 41 supra, section $13(\mathrm{~b})(2)$ is the first statutory provision relating to the bookkeeping system behind such statements. The SEC has obtained a broad range of ancillary remedies by consent in its enforcement actions. See Block \& Barton, supra note 8, at 45 (describing ancillary relief in forcign payments consent decrees); Farrand, Ancillary Remedies in SEC Civil Enforcement Suits, 89 HARv. L. REv. 1779, $1779-1805$ (1976) (describing increasing trend of granting ancillary relief and rationale behind different measures). The courts, however, had questioned the power of the SEC to impose these remedies without the consent of the corporation prior to the adoption of the FCPA. See generally SEC v. Falstaff Brewing Corp., [1978 Transfer Binder] FEd. SEc. L. REP. (CCH) If 96,583, at 94,473 (D.D.C. Oct. 28, 1978) (absent considerable justification, court should not impose remedies that would regulate areas traditionally left to internal corporate management); Block \& Barton, supra note 8 , at $45-46$.

94. See Hycel, Inc., Exchange Act Release No. 14,981, [1978 Transfer Binder] FED. SEc. L. REP. (CCH) $\ 81,676$, at 80,730 (July 20, 1978) (adoption of internal accounting procedures under consent decree in SEC administrative proceedings particularly appropriate in light of enactment of section $13(b)(2)$ ). An example of the type of injunctive relief the SEC will be able to achieve in contested proceedings under section $13(\mathrm{~b})(2)$ is provided by the consent decree obtained by the SEC in its enforcemnt action against ITT for the making of questionable foreign payments prior to the FCPA. See SEC v. ITT, [1979 Transfer Binder] Fed. SEc. L. Rep. (CCH) 9 96,948, at 95,959 (D.D.C. Aug. 8, 1979) (requiring ITT to make and keep accurate books and records and devise and maintain adequate system of internal accounting controls, in language identical to that of section 13(b)(2), even though action arose prior to enactment of section). 
bribery area, the SEG should adhere to guidelines based on investment analysis principles. Mandatory public disclosure of internal control systems or defects, for example, cannot be justified by their informative effect on investors or shareholders. ${ }^{95}$ If internal control defects do not affect reported earnings, or if earnings can be determined by extended auditing procedures, ${ }^{96}$ then investor predictions of future returns will not be affected. Moreover, reports on the condition of past recording or accounting control systems cannot aid in predicting the future cashgenerating ability of the corporation. ${ }^{97}$ Judging from minimal market price reactions in the past to similar disclosures, ${ }^{98}$ information regarding the extensiveness of internal accounting controls is unlikely to affect

95. The burden of such a required report would be extensive, for the scope of the auditor's examination and responsibility would be greatly expanded in that, contrary to common belief, see COHEN COMMrssion REPORT, supra note 40, at 183.84 (survey showed belief that auditor's standard report provided investors and shareholders with moderate to high levels of assurance about adequacy of internal control system), the independent auditor does not now examine the internal control system as such to determine its adequacy or recommend suggestions for improvement to management. Under existing auditing standards, the auditor makes a study and evaluation of the internal accounting control system for the limited purpose of forming a basis to determine the extent of the tests and scope of the examination of the financial statements, see AMERICAN INSTITUTE OF CERTIFIED Public Accountants, supra note $18, \S 323.02$, although the auditor is required to communicate material weaknesses in internal accounting control that come to his attention during his examination of the financial statemenis in a so-called management letter, see id. $\$ 323.04$. The decision not to study the internal control system as such to evaluate its adequacy is a cost-benefit decision, see $i d$. $\$ 323.03$; the auditor "focuses directly on ... preventing or detecting material errors and irregularities" in the financial statements. $I d . \$ 320.65$.

ITT had estimated it would incur additional costs of $\$ 3$ million if the proposed management report were adopted. ITT, Response to SEC Proposed Statement of Management on Internal Accounting Control 7 (July 20, 1979) (on file with SEC).

96. Under existing auditing practices, the auditor forms an opinion on the reliability of the financial statements by both testing the internal control system and testing the details of transactions, with the reliance on each determined by considering the relative effectiveness and efficiency of the two tests in the circumstances. See American INSTITUTE OF Certified Public Accountants, supra note 18, $\$ 320.70-.73$. If the auditor finds material weaknesses in the internal control system, he is thus permitted to expand his testing of transactions to satisfy himself as to the adequacy of the financial statements, without undertaking an extensive evaluation or overhaul of the internal control system, because such evaluation might be more costly than testing the reported transactions and would not achieve any greater financial statement accuracy. However, if the defects in internal control are so extensive that he could not rely on it, even with extensive evaluation, he must expand his testing of transactions. See id.

97. See note 102 infra. Accounting control and recording deficiencies, as accounting functions, also do not affect the actual cash-generating ability of the corporation.

98. See note 58 supra. In fact, the SEC justified its actions to force disclosure of ques. tionable payments prior to the FCPA on the ground that such foreign payments affected the risks of the corporation's operations, and hence were material to investors. See notes 31 \& 51 supra. If the payments did not affect reported earnings from the operations, however, such as if they were mislabeled as other expenses, then such payments would not necessarily affect the riskiness of operations because such payments could be customary and prerequisite to doing business, and hence not reflecting on the corporation's competitive strength. See Note, supra note 51, at 1859. 
the investment risk component. Such information probably is not sufficiently relevant to evaluations of management competency or predictions of future earnings fluctuations.

Narrative internal control disclosures also cannot be justified in terms of their informative value for shareholder voting. The board of directors, and not the shareholders, is responsible for electing the management, supervising its day-to-day operations, and judging its competence. ${ }^{90}$ Because shareholders have no power to design, approve, or disapprove management administrative or accounting functions, and would rather disinvest than vote anyway, ${ }^{100}$ internal control disclosures would serve no protective role ${ }^{101}$ and should not be mandated. ${ }^{102}$

\section{Conclusion}

Congress incorporated accounting provisions into the Foreign Corrupt Practices Act in order to reinforce the protective disclosure system of the Exchange Act. Such provisions, though vaguely framed, can serve a protective role in strengthening the accuracy of financial disclosures

99. Friedman \& Leonard, supra note 59, at 15 .

100. See p. 1587 supra.

101. Similarly, it appears that the SEC program of foreign payment disclosures prior to the FCPA served no protective role. See Weiss, Governance, Disclosure, and Corporate Legitimacy, in AMERICAN ASSEMBLY, supra note 10, at 58, 76 (no incumbent directors of corporations that admitted making questionable payments were deposed as consequence of dissident shareholder campaigns and few of shareholder proposals challenging such payments received great support). The courts, moreover, have rejected claims attacking proxy statements for failure to disclose questionable foreign payments. See Lewis v. Valley, [1979-80 Transfer Binder] FED. SEC. L. REP. (CCH) I 97,179 (S.D.N.Y. July 2, 1979) (nondisclosure of Singer Co. foreign payments not material to shareholder vote on executive compensation and stock option plans); Lewis v. Elam, [1977-78 Transfer Binder] FED. SEc. L. REP. (CCH) \96,013, at 91,555 (S.D.N.Y. Apr. 5, 1977) (proxy solicitation not a link to accomplishment of improper payments); Limmer v. General Tel. \& Elec. Corp., [1977-78 Transfer Binder] Fed. SEc. L. REP. (CCH) \96,111, at 92,002 (S.D.N.Y. Mar. 21, 1977) (connection between exercise of corporate suffrage and acts of waste, improper payments, "too tenuous to support" federal intervention in state law cause of action).

If a member of the board is involved in management dishonesty or fraud, however, and is up for reelection, then such conduct would be material to shareholders in deciding how to vote, and hence is disclosable. See SEC v. Kalvex, Inc., [1975-76 Transfer Binder] FED. SEC. L. REP. (CCH) $\$ 95,226$, at 98,187 (S.D.N.Y. July 7, 1975) (Kalvex proxy statement was defective for not disclosing involvement in various kickback schemes of officer and director up for reelection).

102. See note 42 supra. The accounting profession has also declined to require management internal control reports on the grounds that such reports could even be misunderstood and misleading. See American Institute of Certified Public Accountants, supra note 18, $\$$ 640.03-.09; Deloitte, Haskins \& Sells, Response to SEC Proposed Statement of Management on Internal Accounting Control 3-4 (Aug. 14, 1979) (on file with SEC). The profession still believes an SEC-required management report on internal controls would be misleading to general readers because they might not realize that such reports could not add credibility to prior audited financial statements or provide assurance that management stewardship objectives will be met in the future. See id. at 6-7. 
if enforced with a view to disclosure materiality. They should not, however, be interpreted to allow a more direct role for the SEC in internal corporate affairs. Restructuring and regulating corporate decisionmaking, if desired, ${ }^{103}$ should be effected not through SEC disclosure discretion, but rather through direct legislation following public debate. ${ }^{104}$

103. Commentators criticizing the concentration of economic power in corporate form and the increasing separation of corporate control from ownership have argued that because owners have become content with a passive role, they have surrendered their right to have corporate activity regulated in their economic interest to the interests of the community at large. See, e.g., A. Berle \& G. Means, The Modern Corporation and Private Property 355-56 (1933). Under this view, the corporation should become a more public, social institution whose decisionmaking should be monitored in the public interest. See id. at 356-57; Schoenbaum, The Relationship Between Corporate Disclosure and Corporate Responsibility, 40 Fordham L. REv. 565, 578 (1972). Other commentators, however, have questioned the desirability of such a regulatory framework. See, e.g., R. Posner, Economic ANAlysis of LAw 289.313 (2d ed. 1977) (describing economic efficiency of corporate form and separation of management and ownership); Manning, Corporate Power and Individual Freedom: Some General Analysis and Particular Reservations, 55 Nw. U.L. REv. 38 (1960) (calling for concentration on particular undesirable corporate acts rather than on general "corporate power" and "unpropertied" and "disenfranchised" shareholders); Ruder, Public Obligations of Private Corporations, 114 U. PA. L. REv. 209, 213-15 (1965) (describing proposition that the competitive pursuit of profit is desirable for the economy).

104. Direct legislation could take one of any number of suggested forms, including public directorships, representative boards, federal incorporation, federal minimum standards, or uniform corporate structure. See R. NAder, M. Green \& J. Seligman, supra note 85 (advocating federal incorporation law); C. STONE, WHERE THE LAW ENDS 152-73 (1975) (discussing modern corporate influence and suggesting general public directors); Cary, Federalism and Corporate Law: Reflections Upon Delaware, 83 YALE L.J. 663 (1974) (advocating minimum federal standards of corporate responsibility). Such legislation would replace the existing disclosure framework under the Securities Acts, providing managers with more explicit guides to the proper scope of their activity and the extent of their liability. 